УДК 576.4, DOI 10.31210/visnyk2018.04.34

(C) 2018

\author{
Молчанова А. В., аспірант
}

(науковий керівник - доктор сільськогосподарських наук, професор, член-кореспондент інженерної Академї України П. В. Писаренко)

Полтавська державна аграрна академія

\title{
ВПЛИВ ПОЛТАВСЬКОГО ПОЛІГОНІУ ТВЕРДИХ ПОБУТОВИХ ВІДХОДІВ НА ПИТНУ ВОДУ ТА ВОДНІ ОБ'ЄКТИ
}

\section{Резензент - доктор економічних наук М. С. Самойлік}

У Полтаві експлуатується полігон твердих побутових відходів поблизу селища Макухівка (4 км від Полтави).

Полігон не має ніяких захисних екранів, а на відстані 800 м від полігону протікає річка Коломак.

Забруднені фільтратом трунтові води, щзо течуть до річки Коломак, є серйозним, постійно діючим, багатокомпонентним джерелом забруднення, вплив якого необхідно ліквідувати або мінімізувати, адже p. Коломак впадає у Ворсклу, що несе свою воду в Дніпро

Нижче за течією м. Полтави розташовані міста $i$ села, які користуються поверхневим забором питної води. В їх числі і велике місто Кременчук.

Наведено результати впливу полтавського полігону твердих побутових відходів на питну воду та водні об 'єкти.

Ключові слова: ТПВ (тверді побутові відходи), вплив, вода, питна вода, водні об'єкти, полігон.

Постановка проблеми. Полігони твердих побутових відходів (ТПВ) є небезпечними джерелами забруднення навколишнього середовища. Особливо ті з них, які не обладнані протифільтраційних екраном і експлуатуються без належної ізоляції інертним матеріалом і без необхідного ущільнення відходів, більшість яких на даний час переважає.

Екологічні та санітарно-гігієнічні проблеми у зв'язку з їх експлуатацією практично однакові це негативний вплив на всі компоненти навколишнього середовища, в тому числі, поверхневі і підземні води.

Комплексність даного впливу виявляється також у тому, що забруднення носить полікомпонентний характер, тобто в навколишнє середовище 3 боку полігонів ТПВ різними шляхами надходять різні речовини дуже широкого спектpa.

Чисельність компонентів-забруднювачів постійно збільшується [1].
Аналіз останніх досліджень і публікацій, у яких започатковано розв'язання проблеми. У більшості публікацій, де досліджується проблематика забруднення вод полігонами ТПВ, визначається склад фільтрату та способи його очищення і недостатньо уваги приділено актуальній проблематиці - аналізу забруднення водойм.

Гелетухою Г. Г. та 3. А. Марценюком проаналізовано технології видобутку і використання біогазу на полігонах ТПВ.

Онищенко С. В. і Самойлік М. С. досліджено проблематику забруднення НПС в системі сталого розвитку регіонів України у роботі «Еколого-економічна оцінка забруднення навколишнього середовища в системі екологічно безпечного розвитку регіонів України».

Загальні теоретичні питання щодо екологічних аспектів та ефективності природоохоронних заходів, пов'язаних із вирішенням проблем поводження 3 відходами, розроблялися в працях Балацкого О. Ф., Бистрякова І. К., Борщевського П. П., Буна Э., Вашкулат М. П., Вілсона Д., Горлицького Б. О., Дрейер А. А., Дорогунцова С. І., Качинського А. Б., Лимаренка В. О., Манелис Б. Г., Маторіна С. І., Міщенка В. С., Мельника Л. Г., Хенса Л., Шевчука В. Я. та ін. Никольський К. С., Сігал І. Я., Столберг Ф. В. і інших.

Проте дослідження впливу полігонів ТПВ на навколишнє природне середовище залишається актуальною проблематикою.

Метою даної роботи $\epsilon$ визначення впливу полігонів твердих побутових відходів на навколишнє середовище через визначення наявних перевищень ГДК у воді (питній та водоймах, розташованих поряд із полтавським полігоном ТПВ).

Матеріали і методи досліджень.

Матеріали досліджень: визначення забруднення вод, а саме хімічний аналіз на перевищення гранично допустимих концентрацій.

Методи досліджень: польовий, аналітичний, оцінка. 


\section{1. Зразки проб води, 2014 p.}

\begin{tabular}{|c|c|c|c|c|c|c|}
\hline Показник & $\begin{array}{c}\text { Одиниці } \\
\text { вимірювання }\end{array}$ & $\begin{array}{c}\text { Методика } \\
\text { вимірювання }\end{array}$ & $\begin{array}{c}\text { Коломак } \\
\text { Берег }\end{array}$ & $\begin{array}{c}\text { Коломак } \\
\text { Берег } 2\end{array}$ & Колонка & Фільтрат \\
\hline \multicolumn{7}{|c|}{ Узагальнені показники } \\
\hline Колір & град & \multirow{4}{*}{ ГОСТ 3351-74 } & 25 & 15 & 30 & 140 \\
\hline $\begin{array}{l}\text { Мутність } \\
\text { (по каоліну) }\end{array}$ & мг/дм ${ }^{3}$ & & 1,3 & 0,8 & 2,6 & 98 \\
\hline Запах & бали & & 3 & 1 & 2 & 4 \\
\hline $\mathrm{pH}_{\text {водн }}$ & - & & 7,94 & 7,5 & 6,95 & 9,18 \\
\hline Лужність загальна & мг-екв/ дм ${ }^{3}$ & $\begin{array}{c}\text { ГOC T 31957- } \\
2012\end{array}$ & 1,3 & 1,2 & 1,28 & 92 \\
\hline $\begin{array}{l}\text { Загальна } \\
\text { жорсткість }\end{array}$ & мг-екв/ дм ${ }^{3}$ & $\begin{array}{c}\text { ГOCT 31954- } \\
\quad 2012 \\
\end{array}$ & 5,8 & 6,1 & 6,7 & 8,3 \\
\hline \multicolumn{7}{|c|}{ Біогенні елементи } \\
\hline $\begin{array}{l}\text { Вміст азоту нітрат- } \\
\text { ного }\left(\mathrm{N}-\mathrm{NO}_{3}\right)\end{array}$ & мг/дм ${ }^{3}$ & $\begin{array}{c}\text { ГOCT } 33045- \\
2014\end{array}$ & 10,1 & 28,3 & 3,1 & 10,8 \\
\hline $\begin{array}{l}\text { Вміст азоту нітрит- } \\
\text { ного }\left(\mathrm{N}-\mathrm{NO}_{2}\right)\end{array}$ & $\mathrm{мг} /$ дм $^{3}$ & $\begin{array}{c}\text { ГOCT 18826- } \\
73\end{array}$ & 0,03 & 0,03 & 0,02 & 4,3 \\
\hline Мінералізація & мг/дм ${ }^{3}$ & $\begin{array}{c}\text { ГOCT 18164- } \\
72\end{array}$ & 640 & 658 & 380 & 8920 \\
\hline Вміст аосфатів & мг/дм ${ }^{3}$ & $\begin{array}{c}\text { ГOCT 18309- } \\
2014\end{array}$ & 2,1 & 1,8 & 1,6 & 12,8 \\
\hline Сульфати $\left(50^{-1}\right)$ & $\mathrm{M \Gamma} / \mathrm{dM}^{3}$ & ГОСТ 4389-72 & 168 & 262 & 321 & 558 \\
\hline Хлориди $\left(\mathrm{Cl}^{-}\right)$ & $\mathrm{Mг} / \mathrm{дm}^{3}$ & $\begin{array}{l}\text { ГOCТ 18190- } \\
72\end{array}$ & 284 & 240 & 282 & 641 \\
\hline $\mathrm{XCK}$ & $\mathrm{MrO}_{2} / \mathrm{дM}^{3}$ & ГОСТ 4245-72 & 13 & 15 & 16 & 13276 \\
\hline Нафтопродукти & мг/дм ${ }^{3}$ & $\begin{array}{l}\text { ГОСТ 31859- } \\
2012\end{array}$ & $\leq 0,01$ & $\leq 0,01$ & $\leq 0,01$ & 0,36 \\
\hline Сірководень & мг/дм ${ }^{3}$ & $\begin{array}{c}\text { МУK 4.1.1013- } \\
01\end{array}$ & 0,04 & 0,02 & $\leq 0,01$ & 1,8 \\
\hline \multicolumn{7}{|c|}{ Вміст важких металів } \\
\hline Свинець & мг/дм ${ }^{3}$ & $\begin{array}{c}\text { ГOCT 18293- } \\
72\end{array}$ & 0,38 & 0,92 & 0,01 & 10,3 \\
\hline Хром & $\mathrm{мг} /$ дм $^{3}$ & $\begin{array}{c}\text { ГOCT 31956- } \\
\quad 2012\end{array}$ & 0,06 & 0,1 & 0,02 & 34,2 \\
\hline Залізо & $\mathrm{M} \Gamma / \mathrm{MM}^{3}$ & ГОСТ 4011-72 & 2,38 & 2,23 & 3,82 & 152,1 \\
\hline Кобальт & $\mathrm{Mr} / \mathrm{AM}^{3}$ & MY $31-14 / 06$ & 0,15 & 0,18 & 0,01 & 2,4 \\
\hline Марганець & $\mathrm{мг} /$ дм $^{3}$ & $\begin{array}{c}\text { ГОСТ 4974- } \\
2014\end{array}$ & 0,12 & 0,15 & 0,09 & 1,3 \\
\hline Нікель & $\mathrm{M \Gamma} / \mathrm{дM}^{3}$ & MY $31-14 / 06$ & 0,03 & 0,08 & 0,01 & 3,6 \\
\hline Мідь & мг/дм ${ }^{3}$ & ГОСТ 4388-72 & 1,14 & 1,18 & 0,07 & 15,6 \\
\hline Цинк & мг/дм ${ }^{3}$ & $\begin{array}{l}\text { ГOCT 18293- } \\
72\end{array}$ & 0,4 & 1,06 & 0,02 & 13,7 \\
\hline
\end{tabular}


Результати досліджень. Проведено хімічний аналіз питної води в с. Макухівка, р. Коломак та активно використовуваного населенням для поливу водойому у с. Макухівка.

Дослідження води санітарно-захисної зони полтавського полігону ТПВ у різні роки не показують перевищень ГДК. Нами було зроблено власні дослідження.

Відповідно до Протоколу дослідження №29 від 23 грудня 2014 року (зразки води, 4 шт.), проведеного Лабораторією агроекологічного моніторингу Полтавської державної аграрної академії, було відібрано проби води (табл. 1) 3 річки Коломак зі сторонни полігона ТПВ (проба 1) та з іншого боку (проба 2). В обох пробах відмічено перевищення ГДК цинку, хрому, свинцю, марганцю, міді, кобальта та заліза.

Досліджено пробу води 3 колонки в с. Макухівка. Наявні перевищення ГДК азоту, заліза.

Відповідно до Протоколу дослідження №52 від 30 червня 2015 року, проведеного Лабораторією агроекологічного моніторингу Полтавської державної аграрної академії, було відібрано проби з водойми та фільтрату (табл. 2).

\section{2. Зразки проб води, 2015 р.}

\begin{tabular}{|c|c|c|c|c|}
\hline Показник & $\begin{array}{c}\text { Одиниці } \\
\text { вимірювання }\end{array}$ & $\begin{array}{c}\text { Методика } \\
\text { вимірювання }\end{array}$ & Водойма & Фільтрат \\
\hline \multicolumn{5}{|c|}{ Узагальнені показники } \\
\hline Колір & град & \multirow{4}{*}{ ГОСТ 3351-74 } & 25 & $\begin{array}{c}140 \\
\text { (темно-бурий) }\end{array}$ \\
\hline Прозорість & $\mathrm{CM}$ & & 1 & 5 \\
\hline Запах & бали & & 3 & 4 \\
\hline $\mathrm{pH}_{\text {водн }}$ & - & & 7,21 & 8,98 \\
\hline Лужність загальна & мг-екв/ дм ${ }^{3}$ & $\begin{array}{c}\text { ГOC T 31957- } \\
2012\end{array}$ & 1,2 & 92 \\
\hline \multicolumn{5}{|c|}{ Біогенні елементи } \\
\hline $\begin{array}{l}\text { Вміст азоту нітратного } \\
\left(\mathrm{N}-\mathrm{NO}_{3}\right)\end{array}$ & мг/дм ${ }^{3}$ & $\begin{array}{c}\text { ГОСТ } 33045- \\
2014\end{array}$ & 9,4 & 9,18 \\
\hline $\begin{array}{l}\text { Вміст азотунітритного } \\
\left(\mathrm{N}-\mathrm{NO}_{2}\right)\end{array}$ & мг/дм ${ }^{3}$ & ГОСТ 18826-73 & 0,03 & 3,2 \\
\hline Мінералізація & $\mathrm{M} / \mathrm{Am} \mathrm{M}^{3}$ & ГОСТ 18164-72 & 543 & 9397 \\
\hline Вміст аосфатів & мг/дм ${ }^{3}$ & $\begin{array}{c}\text { ГOCT 18309- } \\
2014\end{array}$ & 18,6 & 132,6 \\
\hline Сульфати (50:-) & $\mathrm{M \Gamma} / \mathrm{AM}^{3}$ & ГOCT 4389-72 & 135 & 854 \\
\hline Хлориди $\left(\mathrm{Cl}^{-}\right)$ & $\mathrm{M \Gamma} / д \mathrm{M}^{3}$ & ГОСТ 18190-72 & 264 & 580 \\
\hline $\mathrm{XCK}$ & $\mathrm{MrO}_{2} / \mathrm{gm}^{3}$ & ГОСТ 4245-72 & 8 & 936 \\
\hline Нафтопродукти & мг/дм ${ }^{3}$ & $\begin{array}{l}\text { ГOC T 31859- } \\
2012\end{array}$ & - & 1,8 \\
\hline Сірководень & $\mathrm{M \Gamma} / \mathrm{дM}^{3}$ & MУK 4.1.1013-01 & 0,2 & 8,0 \\
\hline \multicolumn{5}{|c|}{ Вміст важких металів } \\
\hline Свинець & $\mathrm{M \Gamma} /$ дм $^{3}$ & ГОСТ 18293-72 & 2,7 & 8,7 \\
\hline Хром & мг/дм ${ }^{3}$ & $\begin{array}{l}\text { ГOCT 31956- } \\
2012\end{array}$ & 0,6 & 32,2 \\
\hline Залізо & $\mathrm{M \Gamma} / \mathrm{дm}^{3}$ & ГОСТ 4011-72 & 10,7 & 292,1 \\
\hline Кобальт & $\mathrm{Mr} / \mathrm{дm}^{3}$ & MY $31-14 / 06$ & 0,8 & 64 \\
\hline Марганець & $\mathrm{M \Gamma} / \mathrm{дm}^{3}$ & ГОСТ 4974-2014 & 28,4 & 33,1 \\
\hline Нікель & $\mathrm{M \Gamma} / \mathrm{дm}^{3}$ & MY 31-14/06 & 0,3 & 23 \\
\hline Мідь & $\mathrm{M \Gamma} / \mathrm{дm}^{3}$ & ГOCT 4388-72 & 114 & 181,1 \\
\hline Цинк & мг/дм ${ }^{3}$ & ГОСТ 18293-72 & 421 & 982 \\
\hline
\end{tabular}


Наявні перевищення ГДК кобальта, цинка, заліза, свинцю, хрому, марганцю.

Відповідно до Протоколу дослідження №52 від 30 червня 2015 року проведеного Лабораторією агроекологічного моніторингу Полтавської державної аграрної академії, було відібрано пробу питної води з колонки с Макухівка.

Наявні перевищення ГДК заліза, марганцю, міді.

\section{БІБЛІОГРАФІЯ}

1. Величко О. М., Зеркалов Д. В. Контроль забруднення довкілля: Навч. посіб. - К. : Основа, 2002. - $256 \mathrm{c}$.

2. Войщіховська А. Сучасні екологічні проблеми твердих побутових відходів / А. Войціховська // Екологія. Право. Людина. - 2013. №19/20. - C. 94-96.

3. Губанова E. Р. Глобализационный аспект проблемы твердых отходов / Е. Р. Губанова // Журнал «Экология плюс», 2009. - №1. - С. 27 29.

4. Доспехов Б. А. Методика полевого опыта / Б. А. Доспехов. - М. : Колос, 1979. - 416 с.

\section{ANNOTATION}

Molchanova A. V. The impact of the Poltava landfill on drinking water and water bodies

In Poltava, a landfill for solid waste near the village Makukhovka (4 $\mathrm{km}$ from Poltava) is operated. The landfill has no protective screens, and at a distance of $800 \mathrm{~m}$ from the landfill the Kolomak River flows. The groundwater contaminated by the filtrate flowing to the Kolomak River is a serious, permanent, multicomponent source of pollution, the effect of which must be eliminated or minimized, because Kolomak flows into Vorskla, which carries its water into the Dnieper. Downstream of the Vorskla River not far from Poltava city are located cities and villages which use surface intake of drinking water. Among them there is a big city Kremenchuk. The results of the influence of the Poltava solid waste landfill on drinking water and water bodies are presented.
Висновок. Проаналізувавши отримані дані, можна зробити висновки про істотний негативний вплив полтавського полігону ТПВ на навколишне середовище, а саме вплив на питну воду та водні об'єкти, що розташовані поряд із полігоном, значні перевищення ГДК на вміст важких металів, що становить загрозу для життя та здоров'я людей, які проживають, у першу чергу, в найближчому населенному пункті - в с. Макухівка.

5. Еременко Г. Е. О качественной оценке поливной воды / Еременко Г. Е. // Гидротехника и мелиорация. - 1968. - №7. - С. 63-70.

6. Карюхина T. А. Контроль качества воды. Учебник для техникумов / Т. А. Карюхина, И. Н. Чурбанова - М. : Стройиздат, 1977. - 287 с.

7. Лотоиький О. Б. Проблемы и перспективы в сфере обращения с бытовыми отходами в Украине // Информ. журн. «Строительство и ремонт». - 2003. - №15. - С. 52-53.

8. Новиков Ю. В. Методы исследования качества воды водоемов [под ред. А. П. Шицковой] / Ю. В. Новиков, К. О. Ласточкина. - Москва, 1990. $-400 \mathrm{c}$.

Solid waste landfills (SWL) are dangerous sources of environmental pollution. Especially those of them that are not equipped with an anti-filtration screen and are operated without proper insulation of inert materials and without the necessary compaction of waste.

Environmental and sanitary problems associated with their operation are almost the same, this is a negative impact on all components of the environment, including surface and groundwater.

The complexity of this impact is also revealed in the fact that pollution has a multicomponent nature, that is, various substances of a very wide range enter into the environment from the side of solid waste landfills in various ways and the number of pollutant components is constantly increasing.

Key words: municipal solid waste, impact, water, drinking water, water bodies, landfill. 